\title{
Anaplastic T cell lymphoma in a patient with autoimmune hepatitis and hepatitis $\mathrm{C}$ infection
}

\author{
Hina Ismail, Nishat Akbar, Ghazi Abrar, Arz Mohammad, Syed Zahid Shah, Zain Majid ${ }^{*}{ }^{\circledR}$, Nasir Hassan Luck \\ Department of Hepatogastroenterology, Sindh Institute of Urology and Transplantation, SIUT, Karachi, Pakistan \\ Correspondence to: \\ Zain Majid, \\ Email:Zain88@hotmail.com \\ Received: 13 Apr. 2021 \\ Accepted: 20 June 2021 \\ ePublished: 29 Aug. 2021 \\ Keywords: Anaplastic T cell

\begin{abstract}
Lymphomas are rarely associated with liver disease. We hereby present a case of anaplastic T cell lymphoma in a 45-year-old female, who had received four cycles CHOP chemotherapy regimen and was evaluated for abdominal pain, fever along with weight loss. She was later found to have features of chronic liver disease on ultrasound along with varices on screening endoscopy. Serological workup was positive for hepatitis $\mathrm{C}$ infection while her liver biopsy showed features of autoimmune hepatitis. She was managed with steroids and azathioprine along with direct acting antiviral agents.
\end{abstract} lymphoma, HCV infection, NonHodgkin lymphoma

Citation: Ismail $\mathrm{H}$, Akbar N, Abrar G, Mohammad A, Shah SZ, Majid Z, Hassan Luck N. Anaplastic T cell lymphoma in a patient with autoimmune hepatitis and hepatitis C infection. J Prev Epidemiol. 2021;6(2):e36 doi: $10.34172 /$ jpe. 2021.36

\section{Introduction}

Anaplastic large T-cell lymphoma (ACLC) is a type of non-Hodgkin lymphoma (NHL). It is also known as Ki-1 lymphoma. It is a fast growing lymphoma, which is usually seen in young individuals including children $(1,2)$. ACLC accounts for $2 \%$ of lymphoma. There are two forms of anaplastic large cell lymphoma (ALCL). Primary cutaneous ACLC which is limited to skin and systemic ALCL which involves the organs and the lymph nodes. Systemic ACLC has further divided in to two forms based on ALK gene. ALK positive ALCL accounts for $0.5 \%$ of lymphoma and have better prognosis than the ALK negative ALCL $(3,4)$.

NHL most commonly involves liver, apart from lymph nodes, spleen and bone marrow. Liver biopsy is generally needed to rule out hepatic dysfunctions or deranged liver function test secondary to chemotherapy or other medications. Rarely a lymphoma is associated with other liver diseases such as chronic hepatitis C (5-8).chronic hepatitis B $(9,10)$, primary biliary cirrhosis $(11)$.

\section{Case Report}

A 45-year-old female, known case of ALCL diagnosed on inguinal lymph node biopsy two year ago, underwent 4 cycles of chemotherapy (CHOP), the last one 20 days ago. Shewas referred to gastroenterologyOPD with complaints of right upper abdominal pain, low-grade fever and generalized weakness for 2 months. On general physical examination, she appeared pale, while on

\section{Key point}

HCV infection should be evaluated in patients with $\mathrm{T}$ cell lymphoma. It may occur as a complication of Immunodeficiency state.

examination, her abdomen was soft, with mild tenderness noticed in epigastric region. Laboratory examination revealed plasma hemoglobin $10.1 \mathrm{~g} / \mathrm{dL}$ (normal 11-15 g/dL) with total leukocyte count of $4.3 \times 10$ cells per microliter, platelets $102 \times 10 / \mu \mathrm{L}$, blood urea nitrogen $32 \mathrm{mg} / \mathrm{dL}$, serum creatinine $0.6 \mathrm{mg} / \mathrm{dL}$, a total bilirubin of $1.20 \mathrm{mg} / \mathrm{dL}$, alanine aminotransferase $56 \mathrm{U} / \mathrm{L}$ (normal 0-37 U/L), aspartate aminotransferase 81 (0-40 U/L),alkaline phosphate $127 \mathrm{u} / \mathrm{L}$ (normal 111-150) and albumin $3.7 \mathrm{~g} / \mathrm{dL}$. The international normalized ratio was 1.07. Her serological workup showed anti $\mathrm{HCV}$ positive, $\mathrm{HbsAg}$ negative with $\mathrm{HCV}$ RNA PCR (polymerase chain reaction) was detected. Her autoimmune profile was also sent that showed ANA positive (1:40), anti LKM (anti-liver-kidney microsomal antibodies), ASMA (anti-smooth muscle antibodies) negative and serum IgG levels were raised $(18 \mathrm{~g} / \mathrm{L})$.She underwent CTscan chest, abdomen and pelvis that showed liver measures $15.2 \mathrm{~cm}$ in size, altered parenchymal texture is also seen along with diffuse nodularity, margins are irregular and nodular. Few tiny hypo-dense nodules are noted in both lobes of liver, which are not enhancing on portovenous phase, largest one

Copyright (C) 2021 The Author(s); Published by Society of Diabetic Nephropathy Prevention. This is an open-access article distributed under the terms of the Creative Commons Attribution License (http://creativecommons.org/licenses/by/4.0), which permits unrestricted use, distribution, and reproduction in any medium, provided the original work is properly cited. 
measures $0.6 \times 0.3 \mathrm{~cm}$ in size. No filling defect seen. Spleen measures $13.7 \mathrm{~cm}$ in size, no ascites. A small nodule seen in right lobe of thyroid, few sub-centimeter mediastinal lymph nodes are seen in pre-tracheal and pre-cranial region. She also had liver parenchymal biopsy that showed expanded portal tracts with lymphocytic infiltrates and fibrosis, occasional plasma cells are also noted with foci of piecemeal necrosis and lobulitis also visualized .Florid bile ductular seen. Portal tract to portal tracts bridging fibrosis are noted, forming partial nodules. Modified histologic activity index is 5/6 (partial cirrhosis; Figure 1). Endoscopy revealed three columns of grade I esophageal varices without red sign seen. Multiple erosions seen in body and antrum of stomach, while normal looking mucosa of bulb of duodenum (Figure 2). Then, she was treated with direct acting anti-viral therapy (ribavirin, sofosbuvir and daclatasvir) for three months and based on a simplified score of autoimmune hepatitis of six she was kept on tablet Deltacortril $5 \mathrm{mg}$ and azathioprine $50 \mathrm{mg}$ once daily. She was follow-up after two weeks that showed improved liver function tests with alanine aminotransferase $26 \mathrm{U} / \mathrm{L}$ (normal 0-37 U/L), aspartate aminotransferase $31 \mathrm{U} / \mathrm{L}(0-40)$.

\section{Discussion}

ACLC is a rare entity; it is differentiated from other lymphomas by the expression of CD30 antigen and cytology showing anaplastic cells. It affect children and young adults, it is more common in males than females (12-15).

ACLC is further categorized in to ALK positive lymphoma and ALK negative lymphoma based on the alteration on gene. ALK positive ACLC is a fast growing tumor and effects middle-aged people and it shows good response to chemotherapy and has a better prognosis as compared to ALK negative ACLC which tends to involve elderly people. ALK positive ALCL carries a 10 -year survival rate of $90 \%$, while, ALK negative ALCL contains a stated five-year survival rate of $35 \%$ to $49 \%(16,17)$.

ACLC is classified in to two forms based upon the site of lymphoma. Primary cutaneous ACLC usually involves the skin and they are less aggressive than primary systemic ACLC however (18) primary systemic ALCL involves the lymph nodes. It can involve the lungs, liver, bone marrow, skin and soft tissues (19).

The association between hepatitis $\mathrm{C}$ virus and $\mathrm{T}$ cell lymphoma is indistinct. Several studies have been reported a connotation between HCV infection and B-cell NHL (2025). Few case reports have shown the link between HCV and T-cell lymphomas. Our case is the first case, which showed the association between HCV and anaplastic T cell lymphoma.

\section{Conclusion}

In conclusion, $\mathrm{HCV}$ infection should be evaluated in patients with $\mathrm{T}$ cell lymphoma. It may occur as a

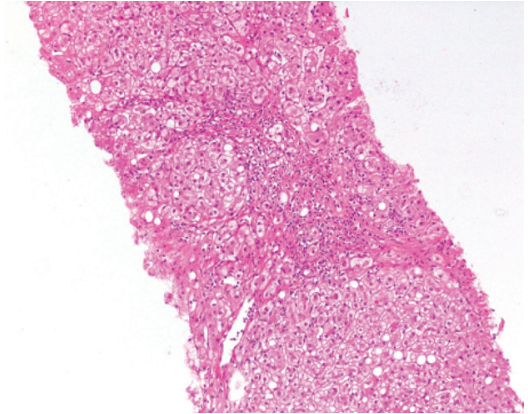

Figure 1. Liver biopsy showed expanded portal tracts with lymphocytic infiltrates and fibrosis, occasional plasma cells are also noted with foci of piecemeal necrosis and lobulitis also visualize with bridging fibrosis.

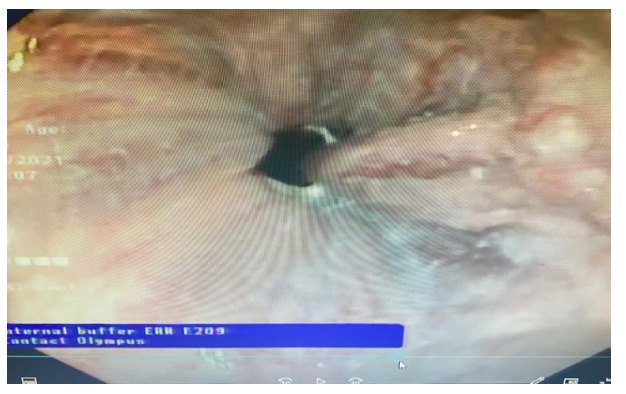

Figure 2. The evidence of grade I varices as seen on the endoscopy image

complication of Immunodeficiency state. Additional studies should be conducted to define the association between HCV infection and T cell lymphomas.

\section{Authors' contribution}

Case management by MZ, IA, AN, MA, SSZ and HLN. Manuscript drafting by ZM. All authors read and signed the final paper.

\section{Conflicts of interest}

The authors declare that they have no competing interests.

\section{Ethical issues}

Ethical issues (including plagiarism, data fabrication, double publication) have been completely observed by the authors. The patient gave the consent to publish as a case report.

\section{Funding/Support}

None.

\section{References}

1. Stein H, Mason DY, Gerdes J, O'Connor N, Wainscoat J, Pallesen $\mathrm{G}$, et al. The expression of the Hodgkin's disease associated antigen $\mathrm{Ki}-1$ in reactive and neoplastic lymphoid tissue: evidence that Reed-Sternberg cells and histiocytic malignancies are derived from activated lymphoid cells. Blood. 1985;66:848-58.

2. Harris NL, Jaffe ES, Stein H, Banks PM, Chan JK, Cleary ML, et al. A revised European-American classification of lymphoid neoplasms: a proposal from the International Lymphoma Study Group. Blood. 1994;84:1361-92.

3. Kadin ME. Primary Ki-1-positive anaplastic large-cell lymphoma: a distinct clinicopathologic entity. Ann Oncol. 1994;5:25-30. doi: 10.1093/annonc/5.suppl_1.s25.

4. Filippa DA, Ladanyi M, Wollner N, Straus DJ, O'Brien JP, 
Portlock C, et al. CD30 (Ki-1)-positive malignant lymphomas: clinical, immunophenotypic, histologic, and genetic characteristics and differences with Hodgkin's disease. Blood. 1996;87:2905-17.

5. Ascoli V, Lo Coco F, Artini M, Levrero M, Martelli M, Negro F. Extranodal lymphomas associated with hepatitis $\mathrm{C}$ virus infection. Am J Clin Pathol. 1998;109:600-9. doi: 10.1093/ ajcp/109.5.600.

6. Bronowicki JP, Bineau $C$, Feugier $\mathrm{P}$, Hermine $\mathrm{O}$, Brousse $\mathrm{N}$, Oberti $\mathrm{F}$, et al. Primary lymphoma of the liver: clinicalpathological features and relationship with HCV infection in French patients. Hepatology. 2003;37:781-7. doi: 10.1053/ jhep.2003.50121.

7. Dammacco F, Gatti P, Sansonno D. Hepatitis C virus infection, mixed cryoglobulinemia, and non-Hodgkin's lymphoma: an emerging picture. Leuk Lymphoma. 1998;31:463-76. doi: 10.3109/10428199809057606.

8. Möhler M, Gutzler F, Kallinowski B, Goeser T, Stremmel W. Primary hepatic high-grade non-Hodgkin's lymphoma and chronic hepatitis C infection. Dig Dis Sci. 1997;42:2241-5. doi: 10.1023/a:1018858415936.

9. Matano S, Nakamura S, Annen Y, Hattori N, Kiyohara K, Kakuta K, et al. Primary hepatic lymphoma in a patient with chronic hepatitis B. Am J Gastroenterol. 1998;93:2301-2. doi: 10.1111/j.1572-0241.1998.00648.x.

10. Ozaki S, Ogasahara K, Kosaka M, Inoshita T, Wakatsuki S, Uehara $\mathrm{H}$, et al. Hepatosplenic gamma delta T-cell lymphoma associated with hepatitis B virus infection. J Med Invest. 1998; 44:215-7.

11. Prabhu RM, Medeiros LJ, Kumar D, Drachenberg Cl, Papadimitriou JC, Appelman HD, et al. Primary hepatic lowgrade B-cell lymphoma of mucosa-associated lymphoid tissue (MALT) associated with primary biliary cirrhosis. Mod Pathol. 1998;11:404-10.

12. Shustov A, Soma L. Anaplastic Large Cell Lymphoma: Contemporary Concepts and Optimal Management. Cancer Treat Res. 2019;176:127-44. doi: 10.1007/978-3-319-997162_6.

13. Dalla-Favera R, Gaidano G. DeVita VT Jr, Hellman S, Rosenberg SA, eds. Cancer: Principles and Practice of Oncology. 6th ed. Philadelphia, Pa: Lippincott Williams \& Wilkins; 2001. Vol 2: 2215-387.

14. Stein H, Foss HD, Dürkop H, Marafioti T, Delsol G, Pulford K, et al. CD30(+) anaplastic large cell lymphoma: a review of its histopathologic, genetic, and clinical features. Blood. 2000; 96:3681-95.

15. Bennani-Baiti N, Ansell S, Feldman AL. Adult systemic anaplastic large-cell lymphoma: recommendations for diagnosis and management. Expert Rev Hematol. 2016; 9:137-
50. doi: 10.1586/17474086.2016.1122514.

16. Savage KJ, Harris NL, Vose JM, Ullrich F, Jaffe ES, Connors $J M$, et al. International Peripheral T-Cell Lymphoma Project. ALK- anaplastic large-cell lymphoma is clinically and immunophenotypically different from both ALK + ALCL and peripheral T-cell lymphoma, not otherwise specified: report from the International Peripheral T-Cell Lymphoma Project. Blood. 2008;111:5496-504. doi: 10.1182/ blood-2008-01-134270

17. ten Berge RL, Oudejans JJ, Ossenkoppele GJ, Pulford K, Willemze R, Falini B, et al. ALK expression in extranodal anaplastic large cell lymphoma favours systemic disease with (primary) nodal involvement and a good prognosis and occurs before dissemination. J Clin Pathol. 2000;53:445-50. doi: 10.1136/jcp.53.6.445.

18. Kadin ME. Primary Ki-1-positive anaplastic large-cell lymphoma: a distinct clinicopathologic entity. Ann Oncol. 1994;5:25-30. doi: 10.1093/annonc/5.suppl_1.s25.

19. Filippa DA, Ladanyi M, Wollner N, Straus DJ, O'Brien JP, Portlock $\mathrm{C}$, et al. CD30 (Ki-1)-positive malignant lymphomas: clinical, immunophenotypic, histologic, and genetic characteristics and differences with Hodgkin's disease. Blood. 1996; 87(7):2905-17.

20. Ferri C, Caracciolo F, Zignego AL, La Civita L, Monti M, Longombardo G, et al. Hepatitis $\mathrm{C}$ virus infection in patients with non-Hodgkin's lymphoma. Br J Haematol. 1994; 88:3924. doi: 10.1111/j.1365-2141.1994.tb05036.x.

21. Pozzato G, Mazzaro C, Crovatto M, Modolo ML, Ceselli S, Mazzi G, et al. Low-grade malignant lymphoma, hepatitis C virus infection, and mixed cryoglobulinemia. Blood. 1994; 84:3047-53.

22. Mele A, Pulsoni A, Bianco E, Musto P, Szklo A, Sanpaolo MG, et al. Hepatitis $C$ virus and B-cell non-Hodgkin lymphomas: an Italian multicenter case-control study. Blood. 2003; 102:9969. doi: 10.1182/blood-2002-10-3230.

23. Duberg AS, Nordström M, Törner A, Reichard O, Strauss $R$, Janzon $R$, et al. Non-Hodgkin's lymphoma and other nonhepatic malignancies in Swedish patients with hepatitis C virus infection. Hepatology. 2005;41:652-9. doi: 10.1002/ hep.20608.

24. Anderson LA, Pfeiffer R, Warren JL, Landgren O, Gadalla S, Berndt $\mathrm{SI}$, et al. Hematopoietic malignancies associated with viral and alcoholic hepatitis. Cancer Epidemiol Biomarkers Prev. 2008;17:3069-75. doi: 10.1158/1055-9965.EPI-080408.

25. Dal Maso L, Franceschi S. Hepatitis C virus and risk of lymphoma and other lymphoid neoplasms: a meta-analysis of epidemiologic studies. Cancer Epidemiol Biomarkers Prev. 2006;15:2078-85. doi: 10.1158/1055-9965.EPI-06-0308. 